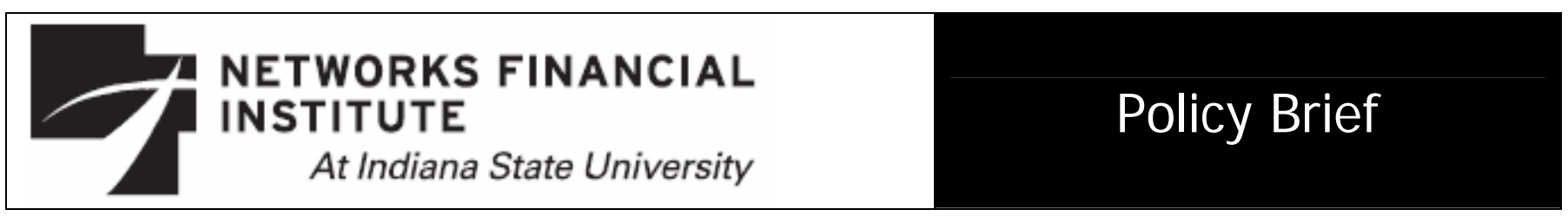

2007-PB-11

October 2007

\title{
A Program for Minimizing the Private and Public Costs of Bank Failures George G. Kaufman
}

Abstract: Bank failures are often perceived to be more costly to the economy than the failure of other firms of comparable size and to generate widespread public fear. As a result, preventing bank failures is a major public policy concern in all countries. Unfortunately, most public policy strategies adopted in nearly all countries to achieve this objective have eventually failed to do so, at a large cost, not only in reduced income and wealth to the failed bank's customers and in the bank's market area, but also to the taxpayers of the country as a whole, who have frequently been asked to finance most or all of the losses to bank depositors, other creditors, and, at times, even shareholders. The high cost of these policies has encouraged a search for more efficient ways of protecting the economy from bank failures, while permitting poorly managed or unlucky individual banks to exit but at no or little cost to either their customers or the economy. This paper proposes a four-pillar program to achieve this objective efficiently.

About the Author: George G. Kaufman is the John F. Smith Professor of Finance and Economics and Director of the Center for Financial and Policy Studies in the School of Business Administration, Loyola University, Chicago. Before teaching at Loyola, he was a research fellow, economist and research officer at the Federal Reserve Bank of Chicago and has been a consultant to the Bank since 1981. Kaufman received his B.A. from Oberlin College, M.A. from the University of Michigan, and Ph.D. in economics from the University of lowa. Professor Kaufman's teaching and research interests are in financial economics, institutions, markets and regulation and in the Federal Reserve and monetary policy. He has lectured widely in the U.S. and abroad and published extensively in professional journals, as well as having been an editor or a member of the editorial board of several major journals. He is also the author or editor of numerous books. In May 2003, the Economist identified Kaufman as one of "America's leading financial economists." Professor Kaufman has served as a consultant to numerous government agencies and private firms. He has frequently testified before Congress and other legislative and policy groups.

Keywords: bank failure, failure resolution, bank regulation

The views expressed are those of the individual author and do not necessarily reflect official positions of Networks Financial Institute. Please address questions regarding content to George Kaufman at gkaufma@luc.edu. Any errors or omissions are the responsibility of the author.

NFI working papers and other publications are available on NFI's website (www.networksfinancialinstitute.org). Click "Research" and then "Publications/Papers." 


\section{A Program for Minimizing the Private and Public Costs of Bank Failures George G. Kaufman}

Bank failures are often perceived to be more costly to the economy than the failure of other firms of comparable size and to generate widespread public fear. As a result, preventing bank failures is a major public policy concern in all countries. Unfortunately, most public policy strategies adopted in nearly all countries to achieve this objective have eventually failed to do so, at a large cost, not only in reduced income and wealth to many of the failed bank's customers and in the bank's market area through misallocation of financial resources, but also to the taxpayers of the country as a whole, who have frequently been asked to finance most or all of the losses to bank depositors, other creditors, and, at times, even shareholders. The high cost of these policies has encouraged a search for more efficient ways of protecting the economy from bank failures, while permitting poorly managed or unlucky individual banks to exit but at no or little cost to either their customers or the economy. This paper proposes a four-pillar program to achieve this objective efficiently. ${ }^{1}$

\section{Four Pillar Program to Minimize Costs of Bank Failures}

Bank failures generally involve direct losses to shareholders, depositors, other creditors, and borrowers. Because bank deposits serve as both money and liquid wealth and banks are typically closely interconnected through interbank deposits and loans, so that the losses may spill over to other banks and beyond, it is losses to bank stakeholders other than the shareholders that create the adverse externalities and are of primary public policy concern. Losses to depositors may be in two forms. One, credit losses, which occur if the recovery values of the assets fall short of the par value of the deposits. Two, liquidity

\footnotetext{
${ }^{1}$ Kaufman (2004a). Similar programs have been proposed by Mayes (2004) and Harrison (2005).
} 
losses, which occur when depositor access to the either insured or the asset recovery value of their uninsured deposits is delayed. The accounts are frozen for some length of time. Short-term deposits are effectively transformed into longer-term deposits or even bonds. Liquidity losses may also be experienced by borrowers, if performing loan customers cannot access their prearranged credit lines. Liquidity losses tend to receive less attention than credit losses, at least in the U.S., even though they are as, if not more, damaging than credit losses. If there were no fear of either credit or liquidity losses, there would be no need either for depositors to run on their banks to withdraw funds in mass in anticipation of credit losses. Such runs could induce fire-sale losses from the resulting sale of assets and potentially drive a bank into insolvency or force banks to curtail access to legitimate credit lines and decrease the money supply, if depositors run into currency that is not redeposited in other banks. It follows that the cost of bank failures may be minimized by reducing, if not eliminating altogether, credit and liquidity losses.

Before discussing how this may be done, it is important to note that deposit insurance, which is the current policy of choice of most governments for minimizing the frequency and cost of bank failures, does not eliminate either credit or liquidity losses from bank failures. Rather, deposit insurance primarily shifts credit losses from depositors to the insurance agency and, if not priced correctly, may even actually increase these losses. If the insurance is underpriced, as is often the case, banks are likely to pursue excessive risk-taking moral hazard behavior. This is likely to increase the probability of failure. In addition, by reducing the urgency for explicitly or implicitly insured depositors to run, when banks encounter financial difficulties, insolvent banks may not lose funding and continue to operate for some time. As a result, regulators may not feel the urgency to take strong action to place financially troubled banks into receivership and thereby encounter the wrath of bankers, who would lose their institutions; of 
depositors, whose unbooked implicit losses would be transformed into booked and explicit painful losses; and of loan customers, whose access to ongoing bank credit lines would be curtailed. If so, as losses are likely to increase on average the longer insolvent banks are permitted to operate, the regulators would be poor agents for their healthy bank or taxpayer principals. Lastly, deposit insurance per se protects insured depositors against credit losses but not necessarily against liquidity losses, unless the powers of the insurance agency are augmented beyond those required to make depositors whole over time.

All four pillars in the proposed program to minimize or even eliminate credit and liquidity losses in bank failures focus on the word "prompt" and assume that the legal and institutional frameworks, as well as the political will on the part of regulators and governments to permit the proposed remedial actions on a meaningful and timely basis, are in place. ${ }^{2}$ Accordingly, the examples of such remedies used in this paper are restricted primarily to the United States, where these prerequisites largely exist. The four pillars are:

1. Prompt legal closure at positive capital to minimize credit losses,

2. Prompt estimates of credit losses (asset recovery values) and allocation of losses (haircuts) to ex-ante at-risk stakeholders,

3. Prompt reopening of most closed banks under new private or FDIC (bridge bank) ownership to minimize liquidity losses, and

\footnotetext{
${ }^{2}$ An analysis of the current status of bank regulation and institutional arrangements across countries appears in Barth, Caprio, and Levine (2006).
} 
4. Prompt reprivatization and recapitalization of reopened banks.

\section{Pillar One: Prompt Legal Closure}

To minimize if not eliminate credit losses, a bright line legal closure rule at positive capital needs to be incorporated in the statute and the bank's insurance and charter revoked and the bank placed in receivership as soon as or shortly after this line is breached. If successful, losses would be confined to shareholders. As assets are sufficient to cover the remaining liabilities, depositors and other creditors suffer no losses. It is important to differentiate between legal closure and physical closure. Legal closure refers to revoking the insolvent bank's charter and placing it in receivership or conservatorship when the capital of a bank declines below a prespecified positive capital-asset ratio. Generally this is done with the expectation of quickly selling, merging, or bridging all but the smallest banks or banks for which there is no demand to minimize liquidity losses. Physical closure denies customers temporary access to their accounts and creates liquidity losses. Thus, prompt legal closure of banks at the specified capital value is desirable, while physical closure is not.

A legal closure target at a positive value of capital rather than zero, which generally defines insolvency, is desirable as regulators may not always be successful in placing a bank in receivership before all of its capital is fully depleted, because of delays in obtaining and analyzing real-time accurate data, abrupt changes in asset and liability values, or outright fraud. Legally closing a bank quickly when the capital closure trigger is breached is more likely when both the authority and implementation to do so lie administratively with the bank regulatory agencies, with little if any provisions for ex-ante appeal by 
stakeholders, rather than lie judicially in the courts with provisions for ex-ante appeal. In the U.S., these powers are granted the federal banking regulators in a separate bank bankruptcy code from the general corporate bankruptcy code. ${ }^{3}$ Any positive capital remaining after legal closure and sale or liquidation is returned to the bank's shareholders at time of closure. Thus, there is no taking of private property.

To reduce the probability of the bank breaching the insolvency capital trigger either abruptly or without the awareness of the regulators, the legal closure rule needs to be supplemented by an accompanying series of regulatory sanctions that become progressively harsher and more mandatory as the financial condition of an institution, as measured by, say, its capital-asset ratio, deteriorates. The purpose of these multi-tiered prompt corrective action (PCA) sanctions is not to punish troubled banks but to apply a carrot-stick approach to encourage them to reverse their downward direction and recapitalize to avoid insolvency. Only when these sanctions fail to turn a troubled institution around before insolvency is legal closure required. The regulatory sanctions are basically the same as those that the market would typically impose on troubled firms in non-regulated industries, such as limiting dividends, acquisitions, and growth, and preparing capital restoration plans. By making the sanctions progressively harsher as the financial performance of a bank deteriorates, the PCA structure attempts to constrain excessive moral hazard risk-taking behavior by the banks based on the existence of an underpriced safety net and reduce the moral hazard problem. By making the sanctions progressively more mandatory, the PCA structure attempts to reduce the ability of regulators to forbear in applying effective sanctions and reduce the principal-agent problem. ${ }^{4}$

\footnotetext{
${ }^{3}$ The unique features of the bankruptcy code for banks are described in Bliss and Kaufman (2007). In addition, in many countries, the deposit insurance agencies differ greatly from the FDIC in the U.S. They are generally only cash boxes collecting premiums and paying depositors but without any regulatory or supervisory responsibilities or resolution authority. A description of a number of these agencies outside the U.S. appears in Eisenbeis and Kaufman (2007).

${ }^{4}$ The development of the PCA structure in the U.S. enacted in the FDIC Improvement Act (FDICIA) of 1991 is described in Benston and Kaufman (1993).
} 
In addition, by requiring regulators to intervene well before a bank’s financial health deteriorates to the point where it is classified as regulatory, if not economically, insolvent, the PCA tranche structure buys the regulators time to become more knowledgeable about the bank, monitor it more carefully, and prepare for the possibility of legal closure while capital is still positive. (The structure of PCA in the U.S. is summarized in Table 1). Legal closure at regulatory insolvency is triggered when a bank's equity capital declines to a small but positive ratio of its assets. In the U.S., for example, regulatory insolvency is triggered when the book value equity to total asset ratio declines below 2 percent and the bank is classified "critically undercapitalized." To achieve credibility and affect the ex-ante behavior by both banks and large ex-ante uninsured depositors, the sanctions and closure rule need to be developed by the regulators before crises occur, widely publicized, and applied without exception. However, the 2 percent book value equity to asset ratio is likely to be too low to prevent all credit losses in legal closures even if the regulatory agencies act quickly on timely and reliable data. But it should serve to minimize losses. The regulators may also legally close a bank for other reasons, such as not being operated in a safe and sound manner or unlikeliness to meet its deposit obligations, as specified in the statute.

\section{Pillar II: Prompt Estimate and Allocation of Credit Losses}

Both to minimize the cost of resolution to the deposit insurance agency or its stakeholders and to encourage effective market discipline by bank shareholders and ex-ante uninsured depositors and other creditors, it is necessary that they share in losses according to their legal priority. Uninsured depositors, who in the U.S. have equal standing with the FDIC and higher standing than unsecured other creditors, 
need to share in losses with the FDIC only if the regulators are not able to legally close the bank before its capital turns negative or before it is sufficiently negative to exceed the bank's nondepositor unsecured creditors. ${ }^{5}$ Shareholders are likely to lose their investments unless the actual recovery amounts exceed the combined par claims of the FDIC, uninsured depositors, and other creditors. By involving regulators well before regulatory insolvency, the multi-tiered PCA structure also provides time for the regulators to both determine the insurance status of individual deposit accounts and to make reasonable projections of expected asset losses when the bank is legally closed. (Additional time may be gained for identifying insured deposits, if necessary, by maintaining the original maturity dates of time deposits rather than accelerating all accounts to mature on the date of legal closure. This is proposed in the resolution plan developed by the Reserve Bank of New Zealand. ${ }^{6}$ )

Similar to the legal closure rule, the policy of imposing losses or "haircuts" on targeted at-risk (uninsured) depositors and other creditors needs to be widely publicized and strictly enforced in order to achieve credibility. Indeed, in the U.S., insolvencies are required to be resolved at least cost to the FDIC by FDICIA of 1991. The Act also explicitly prohibits the FDIC from protecting uninsured claimants against losses in failure resolutions in which the FDIC incurs losses. But there is an exception to leastcost resolution, as is often the case in public policy rules -- the Systemic Risk Exemption (SRE). In instances when policy-makers believe that failure to fully or partially protect these claimants would "have serious adverse effects on economic conditions or financial stability" and "any action or assistance....would avoid or mitigate such adverse effects, the FDIC could provide protection and suffer larger losses than otherwise. By protecting the depositors and other creditors most able to monitor and discipline banks, invoking SRE is likely to reintroduce costly moral hazard behavior by large banks.

\footnotetext{
${ }^{5}$ In the U.S., depositor preference elevates both the FDIC and uninsured domestic depositors above unsecured other creditors. It was enacted in 1993, two years after FDICIA was enacted.

${ }^{6}$ See Harrison (2005)
} 
However, invoking SRE, formerly and inaccurately referred to as “too-big-to-fail” (TBTF), is not easy. ${ }^{7}$ U.S. regulators must successfully hurdle five formidable barriers -- three ex-ante and two ex-post. The exemption must first be recommended to the Secretary of the Treasury by two thirds of both the Board of Directors of the FDIC and the Board of Governors of the Federal Reserve System and approved by the Secretary of the Treasury after consultation with the President. If approved, this needs to be followed by written notification by the Secretary to both the House and Senate Banking Committees. Thereafter, an ex-post audit of the reasons for granting the exemption, the implementation process, and the effectiveness of the actions must be conducted by the Government Accountability Office (GAO) and reported to Congress. Lastly, any loss experienced by the FDIC in protecting uninsured claimants must be reimbursed to the FDIC expeditiously through a special assessment on all banks based on asset size. Losses to the FDIC from such operations may be expected, as otherwise there would be no need for the intervention. The threat of additional charges may be expected to encourage large bank competitors of the failed bank or banks to attempt to dissuade the FDIC and the other regulators from protecting the uninsured depositors at the insolvent banks, at their expense, and possibly permit these banks to continue to operate while insolvent and likely enlarge their losses further at the expense of the solvent banks.

\section{Pillar III: Prompt Reopening of Legally Closed Institutions}

As noted earlier, while deposit insurance protects insured depositors against credit losses, it does not automatically protect them against liquidity losses. To minimize the magnitude of adverse

\footnotetext{
${ }^{7}$ In the U.S., too-big-to-fail did not mean what it said. Insolvent banks were eventually failed, placed in receivership, and at least shareholder interests wiped out. What TBTF actually meant was that a bank was perceived to be too big to impose haircuts on uninsured depositors and possibly other creditors when the bank was legally closed. But even this practice was diminishing through time after the failure of the Continental Illinois Bank in Chicago in 1984. A history and analysis of TBTF in the U.S. appears in Kaufman (2004c).
} 
externalities from bank failures, it is important that liquidity losses are minimized through providing both insured and uninsured depositors speedy access to the appropriate value of their deposits and restoring borrowers to their pre-specified credit lines. ${ }^{8}$ In the U.S. currently, the FDIC pays insured depositors the par value of their deposits effectively the next business day after legal closure, generally by transferring the deposits to an acquiring or designated paying bank. This effectively involves two subpayments. One represents the estimated pro rata recovery value and the second the difference between this payment and the par value of the insured deposit.

At the same time, the FDIC gives uninsured depositors claims in the form of receivership certificates against the eventual pro rata recovery value of the bank's assets. These are paid by the FDIC from the proceeds received as the assets of the bank are liquidated. Because this typically requires some time, during which the depositors have at best only partial access to the total recovery value of the assets and a viable and deep secondary market for these certificates may not develop sufficiently quickly, these depositors suffer liquidity losses. As a result, the FDIC was provided with the authority to advance payments (dividends) to the depositors against the estimate of the recovery value. ${ }^{9}$ But making payment to both insured and uninsured depositors in advance of the receipt of the proceeds from the sale of the bank or its assets requires that the deposit insurance agency either has a sufficient pool of funds available to it or has sufficient borrowing authority, generally at the Treasury.

Because it may be particularly difficult to resolve a large bank quickly by private sale or merger after it breaches the 2 percent critically undercapitalized trigger, and thus maintain seamless depositor and

\footnotetext{
${ }^{8}$ Liquidity losses are discussed at greater length in Kaufman and Seelig (2002) and Kaufman (2004b).

9 For example, in the FDIC's recent resolution of the failure of NetBank, a \$2.5 billion bank in Georgia, on Friday, September 29, 2007, insured deposits were assumed by another bank and available in full to depositors on Monday, October 1 . Holders of uninsured deposits received receivership certificates also on Monday and an accompanying 50 percent payment of the par amount (FDIC, 2007).
} 
borrower access, the FDIC was authorized to charter a temporary FDIC-owned national bridge bank. The FDIC can maximize all aspects of liquidity by transferring to this bank the par value of the insured deposits, a conservative estimate of the pro rata recovery or market (after credit loss) value of the uninsured deposits, and the prearranged credit lines of performing loan customers. The bank is capitalized by the FDIC. The continuity of the services provided by the insolvent bank would be effectively maintained. Such bridging would also preserve any private information the bank may have on its loan and deposit customers, the loss of which is costly and disruptive. If liquidity losses along with credit losses could be successfully minimized, then both the fear of bank failures and the associated incentive to invoke SRE will be greatly diminished.

Unfortunately, outside the U.S., most deposit insurance agencies do not have similar authority or follow similar practices. For example, most agencies do not have a pool of available funds or automatic borrowing authority to make payments to insured and uninsured depositors in advance of receiving proceeds from the sale of the insolvent bank or its assets. In addition, in most countries, the deposit insurance agencies are not required to either inform insured depositors of a bank’s failure or to pay them quickly. Even insured depositors in many of these countries must file claims for payment, and payment may be delayed for months as the insurer collects the proceeds from the sale of the insolvent bank's assets. Thus, insured as well as uninsured depositors may suffer liquidity losses even if they avoid credit losses. ${ }^{10}$

\footnotetext{
10 The importance of providing immediate access to deposits and lines of credit so as to minimize liquidity losses was demonstrated in the recent handling by the regulators in the United Kingdom of the insolvency or near-insolvency of the Northern Rock, a large mortgage specializing bank, in the summer of 2007. Questions about the financial health of the bank sparked a visible run by insured retail depositors. In large part, the run may be attributed to basic flaws in the U.K. deposit insurance system. The system provided insufficient full coverage for small depositors and had no provision for quick payment to either insured or uninsured depositors if the bank were failed. Deposit insurance protected fully only the first $£ 2,000$ (about $\$ 4,000$ ) of deposits and only 90 percent of the next $£ 33,000$ (about $\$ 66,000$ ) of deposits. Thus, most retail depositors realized they would suffer both credit and more severe liquidity losses if the institution failed and that these losses could be avoided by withdrawing funds before failure. Uninsured depositors and creditors both participated in a less visible "wholesale" run and
} 


\section{Pillar IV: Prompt Reprivatization and Recapitalization}

State owned banks (SOBs) and state controlled banks (SCBs), including banks in government receivership or bridged, are notoriously inefficient and, as all deposits are effectively insured by the government, implicitly if not explicitly, frequently can operate for long period of time while insolvent, misallocating resources and increasing losses. ${ }^{11}$ Thus, it is important to fully reprivatize government operated insolvent banks as quickly as can be done efficiently. All but the largest and most complex banks can be sold as a whole or in greater part at the time of legal closure. This is possible as the PCA structure again provides the regulators sufficient time to identify potential buyers and to circulate bidding materials, including estimates of the market value of assets, on a confidential basis to these parties before the date of legal closure. As noted above, to gain additional time to search out ultimate private buyers, large banks may need to be bridged in the U.S under FDIC ownership. However, the potential five year maximum life of such bridge banks in the U.S. is far longer than necessary or desirable to reprivatize even the largest insolvent bank. To prevent the reprivatized banks from quickly following in the footsteps of their predecessors and return to insolvency, they should be required to be sufficiently recapitalized by the new owners, say, to levels, at minimum, consistent with the definition of adequately capitalized, if not well-capitalized, for purposes of PCA.

shortened the maturities of their lending. To stop the run and keep the bank operating, the regulators were left with little option but to guarantee nearly all depositor and other creditor funds not only at Northern, but at all banks that threatened to suffer similar problems. To keep the bank operating beyond then, they later guaranteed new as well as old deposits. As a result, the probability of similar bank turmoil and the cost of its resolution are both likely to be considerably higher in the future. Also in response, effective October 1, 2007, the U.K. increased its insurance coverage to 100 percent of the first £35,000 of deposits. The Treasury then issued a discussion paper on banking reform that attempts to correct these weaknesses in the existing depositor protection structure.

${ }^{11}$ See for example Barth et al, (2006) and Sapienza (2004). 


\section{Summary and Conclusions}

Healthy banks are by far the best protection against bank failure. Financially troubled banks should be turned around under provisions similar to PCA as quickly as possible after the adverse symptoms are first observed. Only if this fails should legal closure occur. But there is a strong incentive for regulators to delay legally closing insolvent banks. Legal closure would, among other things, be an official admission of the failure of the bank and a black mark on the regulators' record, reduce a regulator's chances of being employed by the industry after service as a regulator, and possibly ignite widespread public fear of substantial and costly adverse externalities beyond the insolvent bank. However, such regulatory forbearance is on average costly.

Costs associated with bank failures can be minimized by implementing a program that will minimize, if not eliminate altogether, both credit and liquidity losses. Such a four pillar program is proposed in this paper. The program focuses on 1) prompt legal closure before a bank's capital is fully depleted to minimize credit losses, 2) prompt estimate of losses and assignment of haircuts to ex-ante uninsured depositors and other creditors as well as to the insurance agency to encourage market discipline and reduce costs to the agency, 3) prompt access of bank deposit and performing loan customers to the appropriate value of their eligible accounts or credit lines to minimize liquidity losses, and 4) prompt reprivatization of insolvent banks at minimum capital ratios to avoid misallocation of resources and possible quick returns to insolvency. By attempting to eliminate the costs associated with bank failure, this strategy permits inefficient or unlucky banks to exit at minimum or no cost and maintain efficiency in the banking system. It also is superior to deposit insurance. Insurance only shifts the losses from depositors to the insurer and in the process may actually increase the losses by encouraging both 
excessive moral hazard risk taking by banks and poor agency behavior by regulators that provides forbearance. Moreover, deposit insurance per se does not protect against liquidity losses. Explicit full deposit insurance on small deposits, however, should be retained to provide redundancy in instances that the proposed scheme fails to resolve insolvencies before a bank's capital is depleted so that credit losses may be incurred. This would protect against runs by insured depositors and remove them politically from the resolution process. It also follows that the magnitude of any credit losses is significantly under the control of the appropriate regulatory agency and if losses are minimized, insurance premiums will also be minimized and their structure less important.

But to be successful, the proposed program needs to be approved and in place in advance of bank insolvencies, widely publicly publicized, and implemented without exceptions in order to gain credibility and affect ex-ante behavior. Moreover, it requires an in-place institutional and legal infrastructure that permits and supports the proposed regulatory actions, including full and ex-ante non-appealable authority by regulators to legally close banks at some specified capital ratio greater than zero and rewards regulators with the political will to carry out the provisions of the program. Currently, the majority of the proposed program is probably feasible only in industrial countries that have much of the necessary infrastructure. But even these countries may still require changes in their institutional structure to implement most or all of the program. Other countries are likely to continue to experience higher than necessary costs of bank failures for some time. The United States, which has much of the necessary institutional and legal infrastructure in place, currently appears to have a resolution program in place that satisfies Pillars 1, 2, and 4 reasonably well, but satisfies Pillar 3 only partially at best. Federal regulators have only recently begun to seriously develop and simulate legal closure and resolution strategies and have not publicized those that they have developed. 
The failure of U.S. regulators to focus more on processes for the efficient resolution of large bank insolvencies may be attributed to some extent, to their strong fascination with and devotion to Basel II. Basel II, which is scheduled to be implemented in the U.S. at the beginning of 2008 after a number of delays, is a highly complex three pillar structure to 1) compute minimum capital requirements in relation to a bank’s risk exposure, 2) strengthen supervisory review and enforcement, and 3) enhance market discipline through increased disclosure. But all three pillars have been severely criticized, at least in the U.S., and have required lengthy and detailed responses by the regulators (Herring 2007 and Kaufman 2004d). The recent turmoil in the financial markets in the summer of 2007 have also cast substantial doubt about the wisdom of relying heavily on rating agency credit ratings for small banks and on internal credit risk models for large banks to compute minimum regulatory capital requirements as in Basel II.

This point-counterpoint exchange between the regulators and their critics stretched over a number of years since Basel II was first proposed in 2001 and has absorbed considerable time and energy not only of the regulatory agencies but also of many large banks, consulting firms, policy makers, and academics. Less time and energy remained for other projects (Kaufman, 2007). In the U.S., many students of banking have concluded that Basel II is inferior to the in-place system of PCA for enforcing minimum capital requirements, whether risk-based or not (Kaufman 2005). ${ }^{12}$ And unlike PCA, Basel II does not consider efficient resolution of bank insolvencies. Thus, there was little if any additional incentive for regulators to develop and test such contingency plans and even less to widely publicize any plans adopted before banks failures occurred.

\footnotetext{
12 This was less true in many other industrial countries where PCA, if adopted, was considerably weaker in practice than in the U.S. (Mayes, Nieto, and Wall, 2007).
} 
But, secret plans to reduce the costs of bank failures are likely to be little more effective than no plans at all. The public is likely to act on a different set of expectations that were previously in place and will strongly oppose ex-post surprise or unexpected actions that may impose losses on it. When push comes to shove, as was evidenced in the summer of 2007 in Germany and the U.K., bank regulators are likely to delay or abandon imposing their secret plans if they are tougher and give in to public pressure for protection as usual. 
Table 1

SUMMARY OF PROMPT CORRECTIVE ACTION PROVISIONS OF THE FEDERAL DEPOSIT INSURANCE CORPORATION IMPROVEMENT ACT OF 1991

\begin{tabular}{|c|c|c|c|c|c|}
\hline \multirow[b]{3}{*}{ Zone } & \multirow[b]{3}{*}{ Mandatory Provisions } & \multirow[b]{3}{*}{ Discretionary Provisions } & \multicolumn{3}{|c|}{ Capital Ratios (percent) } \\
\hline & & & \multicolumn{2}{|c|}{ Risk Based } & \multirow{2}{*}{$\begin{array}{l}\text { Leverage } \\
\text { Tier } 1 \\
\end{array}$} \\
\hline & & & Total & Tier 1 & \\
\hline 1. Well capitalized & & & $>10$ & $>6$ & $>5$ \\
\hline 2. Adequately capitalized & $\begin{array}{l}\text { 1. No brokered deposits, except with FDIC } \\
\text { approval }\end{array}$ & & $>8$ & $>4$ & $>4$ \\
\hline 3. Undercapitalized & $\begin{array}{l}\text { 1. Suspend dividends and management fees } \\
\text { 2. Require capital restoration plan } \\
\text { 3. Restrict asset growth } \\
\text { 4. Approval required for acquisitions, } \\
\text { branching, and new activities } \\
\text { 5. No brokered deposits }\end{array}$ & $\begin{array}{l}\text { 1. Order recapitalization } \\
\text { 2. Restrict inter-affiliate transactions } \\
\text { 3. Restrict deposit interest rates } \\
\text { 4. Restrict certain other activities } \\
\text { 5. Any other action that would better } \\
\text { carry out prompt corrective action }\end{array}$ & $<8$ & $<4$ & $<4$ \\
\hline 4. Significantly undercapitalized & $\begin{array}{l}\text { 1. Same as for Zone } 3 \\
\text { 2. Order recapitalization } \\
\text { 3. Restrict inter-affiliate transactions } \\
\text { 4. Restrict deposit interest rates } \\
\text { 5. Pay of officers restricted }\end{array}$ & $\begin{array}{l}\text { 1. Any Zone } 3 \text { discretionary actions } \\
\text { 2. Conservatorship or receivership if } \\
\text { fails to submit or implement plan or } \\
\text { recapitalize pursuant to order } \\
\text { 3. Any other Zone } 5 \text { provision, if such } \\
\text { action is necessary to carry out } \\
\text { prompt corrective action }\end{array}$ & $<6$ & $<3$ & $<3$ \\
\hline 5. Critically undercapitalized & $\begin{array}{l}\text { 1. Same as for Zone } 4 \\
\text { 2. Receiver/conservator within } 90 \text { days with } \\
\text { two possible } 90 \text { day extensions. } \\
\text { 3. Suspend payments on subordinated debt } \\
\text { 4. Restrict certain other activities }\end{array}$ & & & & $<2$ \\
\hline
\end{tabular}

SOURCE: Board of Governors of the Federal Reserve System. 


\section{REFERENCES}

Barth, James R., Gerard Caprio, Jr., and Ross Levine, Rethinking Bank Regulation: Till Angels Govern, Cambridge: Cambridge University Press, 2006.

Benston, George J., and George G. Kaufman, Risk and Solvency Regulation of Depository Institutions: Past Policies and Current Options, New York: Salomon Brothers Center for the Study of Financial Institutions, New York University, 1988.

Benston, George J. and George G. Kaufman, "The Intellectual History of the Federal Deposit Insurance Corporation Improvement Act of 1991,” in George G. Kaufman, ed., Reforming Financial Institutions and Markets in the United States, Boston: Kluwer Academic, 1993, pp 1-18.

Bliss, Robert R. and George G. Kaufman, "U.S. Corporate and Bank Insolvency Regimes: A Comparison and Evaluation,” Virginia Law and Business Review, Spring 2007, pp. 143-177.

Eisenbeis, Robert A. and George G. Kaufman, “Cross Border Banking: Challenges for Deposit Insurance and Financial Stability in the European Union,” Paper presented at Conference on Financial Instability, Supervision, and Central Banks, Helsinki, Bank of Finland, June 7-8, 2007.

Federal Deposit Insurance Corporation, "FDIC Approves the Assumption of the Insured Deposits of NetBank, Alpharetta, Georgia,” Press Releases, September 28, 2007.

Harrison, Ian, “The Reserve Bank of New Zealand's Creditor Recapitalization (BCR) Project: An Option for Resolving Large Banks?” in Douglas D. Evanoff and George G. Kaufman, eds., Systemic Financial Crises: Resolving Large Bank Insolvencies, Singapore: World Scientific, 2005, pp. 397-406.

Herring, Richard J., “The Rocky Road to Implementation of Basel II in the United States,” Working Paper, Philadelphia: University of Pennsylvania, September 2007.

Kaufman, George G., "Basel II is a Costly Distraction on the Road to Minimizing the Societal Costs of Bank Failure,” Working Paper, Chicago: Loyola University Chicago, July 2007.

Kaufman, George G., "Basel II vs. Prompt Corrective Action: Which is Best for Public Policy?,” Financial Markets, Institutions, and Instruments, December 2005, pp. 344-357.

Kaufman, George G., "Bank Regulation and Foreign-Owned Banks," Reserve Bank of New Zealand Bulletin, June 2004a, pp. 65-74.

Kaufman, George G., "Depositor Liquidity and Loss Sharing in Bank Failure Resolutions," Contemporary Economic Policy, April 2004b, pp. 237-249.

Kaufman, George G., “Too Big to Fail in U.S. Banking: Quo Vadis?” in Benton Gup, ed., Too Big to Fail: Policies and Practices in Government Bailouts, Westport, CT.: Praeger, 2004c, pp. 153-167. 
Kaufman, George G., “The Roar That Moused” in Benton Gup, ed., The New Basel Capital Accord, New York: Thomson, 2004d, pp. 39-52.

Kaufman, George G., and Steven Seelig, "Post-Resolution Treatment of Depositors at Failed Banks," Economic Perspectives (Federal Reserve Bank of Chicago), ${ }^{\text {nd }}$ Quarter 2002, pp. 27-41.

Mayes, David G., "Who Pays for Bank Insolvency?” Journal of International Money and Finance, April 2004, pp. 515-551.

Mayes, David G., Maria J Nieto, and Larry Wall, "Multiple Safety-Net Regulators and Agency Problems in the EU: Is Prompt Corrective Action Partly the Solution?” in Harald Benink, Charles Goodhart, and Rosh Maria Lastra, eds., Prompt Corrective Action \& Cross-Border Supervisory Issues in Europe, (Financial Markets Group Special Paper Series 171), London: London School of Economics, April 2007, pp. 62-88.

Sapienza, Paola, "The Effects of Government Ownership on Bank Lending, Journal of Financial Economics, May 2004, pp. 357-384. 